\title{
Caffeine consumption, intoxication, and stress among female university students: a cross-sectional study
}

Deemah A. AlAteeq* (D), Razan Alotaibi, Raneem Al Saqer, Njoud Alharbi, Maram Alotaibi, Reema Musllet and Rana Alraqibah

\begin{abstract}
Background: University students use caffeine to cope with stress in spite of its adverse effects. The purpose of this study is to explore caffeine consumption among university students in Saudi Arabia, as well as its correlation with stress and caffeine intoxication. This cross-sectional study examined a convenience sample of 547 students at Princess Nourah Bint Abdulrahman University (PNU). A self-administrated questionnaire was used to assess caffeine consumption in milligrams per day, stress was assessed by the perceived stress scale (PSS), and caffeine intoxication was assessed using the DSM-5 criteria.

Results: The mean total caffeine consumption was $424.69 \pm 385.31 \mathrm{mg} /$ day. High levels of caffeine consumption were found among students of non-health colleges and students who were undiagnosed with psychiatric disorders ( $p$ values $<0.040$ and 0.027 , respectively). A significant positive correlation was found between caffeine consumption and perceived stress $(p<0.045)$. Only $13.26 \%$ of all participants fulfilled the DSM-5 criteria for caffeine use disorder. The majority of participants showed moderate and high stress levels (69.9\% and 18.7\%).

Conclusion: This study revealed high caffeine consumption and perceived stress levels among female undergraduate students with a significant positive association between them. The results emphasize the importance of educational campaigns about caffeine consumption and intoxication. They also encourage the development of stress management programs. Longitudinal studies need to be designed for evidence-based intervention.
\end{abstract}

Keywords: Caffeine consumption, Intoxication, Stress, Students

\section{Background}

Caffeine is a stimulant of the central nervous system and metabolism that is used for recreational and for medical reasons, such as decreasing physical exhaustion and increasing mental alertness [1]. Caffeine intake has positive and negative effects. The positive effects are enhanced mood and readiness, improved ability to stay conscious and alert, and strengthened exercise performance [2]. On the other hand, negative effects may occur when caffeine intake exceeds $250 \mathrm{mg}$, it can result in a condition called caffeine intoxication. Symptoms include fidgeting,

\footnotetext{
* Correspondence: Dalateeq@gmail.com

Clinical Sciences Department, College of Medicine, Princess Nourah Bint Abdulrahman University, P.O. Box 93949, Riyadh 11683, Saudi Arabia
}

excitement, insomnia, increased urination, gastrointestinal disturbance, muscle twitching, irregular or rapid heartbeat, and psychomotor agitation according to the criteria of the Diagnostic and Statistical Manual of Mental Disorders, fifth edition (DSM-5) [3].

Students experience stressful times in college due to classes, homework, exams, projects, and extracurricular activities [4]. Studies done on college students in Puerto Rico, Saudi Arabia, and Turkey showed that 49\%, 49.5\%, and $58.99 \%$ of them use caffeine as a coping mechanism, respectively $[2,5,6]$. In order to deal with this stress and fulfill academic requirements, college students may consume caffeine in the belief that it can aid their academic performance [4].

\section{Springer Open}

๑ The Author(s). 2021 Open Access This article is licensed under a Creative Commons Attribution 4.0 International License which permits use, sharing, adaptation, distribution and reproduction in any medium or format, as long as you give appropriate credit to the original author(s) and the source, provide a link to the Creative Commons licence, and indicate if changes were made. The images or other third party material in this article are included in the article's Creative Commons licence, unless indicated otherwise in a credit line to the material. If material is not included in the article's Creative Commons licence and your intended use is not permitted by statutory regulation or exceeds the permitted use, you will need to obtain permission directly from the copyright holder. To view a copy of this licence, visit http://creativecommons.org/licenses/by/4.0/. 
In Bahrain, the mean of daily caffeine consumption was assessed among college students. Females were consuming less than males $(246$ and $306 \mathrm{mg} /$ day respectively) [7]. Another study assessed caffeine consumption and sleep habits among a sample of 228 students at Princess Nourah Bint Abdulrahman University (PNU) and found that most of them had high caffeine consumption, and a need for future studies concerning caffeine intoxication was suggested [8]. In this study, we aimed to estimate the level of caffeine consumption among students at health colleges and non-health colleges in PNU and to explore the correlation of caffeine consumption (including all types of caffeinated beverages) with caffeine intoxication and perceived stress.

\section{Methods}

\section{Study design and population}

This cross-sectional study examined a convenience sample of students who were Arabic speakers at the age of 18 years or above at health and non-health colleges at PNU, Riyadh, Saudi Arabia. PNU is the first women's university in the Middle East and also the largest one. It accommodates 33,825 students and includes 18 colleges.

A self-administrated questionnaire was distributed conveniently in October 2019 to 547 students from different colleges. Equal numbers of questionnaires were distributed to health and non-health colleges (humanities, community, and science). The comparison was chosen to be between health and non-health colleges based on the significant differences in the studying years, academic system, training requirements, and healthrelated knowledge. Health college students have an average of 6 years of studying and non-health college students have an average of 4 years. These factors may affect the level of their perceived stress and caffeine consumption.

The consenting process started by going to the students on the campus and explaining to them the study and asks them if they are willing to participate, mentioning that their identity is confidential as it does not require a name or an ID. If they agree to participate, a copy of the questionnaire will be given to them, and they will be encouraged to read the front page thoroughly which has a statement saying "Filling this questionnaire means you agree to be part of this study." It also has the information and purpose of the study and the contact information.

Previous literatures showed that the average daily caffeine consumptions vary from 10 to $11.2 \mathrm{mg} /$ day, and the standard deviation was around $5 \mathrm{mg} /$ day. Gpower software was used to calculate the minimal size required for this study, considering alpha $=0.05$ (level of significance of 95\%) and beta to be 0.20 (power of the study is $80 \%$ ), the minimal sample size required is 548 .

\section{Data collection tool}

The questionnaire included four main divisions. The first one covered demographic characteristics, academicrelated characteristics, and personal clinical history. The second and third divisions covered caffeine consumption and caffeine intoxication. The fourth division assessed perceived stress level by PSS-10. The first three division of the survey were first written in Arabic then translated to English by a professional translator, then reviewed and translated into Arabic by bilingual speakers. Pilot test was done for the Arabic version, and then face validation was done by sending the survey to four mental health professionals. Furthermore, the fourth division involved the Arabic version of PSS-10, which has been validated previously by Chaaya et al. The PSS-10 was translated from English into Arabic, and then it was reviewed by a bilingual psychiatrist. After that, it was back translated into English by the psychiatrist and a comparison with the original one was done [9].

\section{Demographic characteristics, academic-related characteristics, and personal clinical history}

Demographic characteristics included age, nationality, marital status, number of children, and income, which was estimated among students as having enough income, enough income with saving, not enough income, or debt. Academic-related characteristics included college, academic level (first and second-years were counted as "juniors," whereas third, fourth, and fifth years were accounted as "seniors"), GPA, and academic satisfaction. Personal clinical history included questions about their history of diagnosed chronic diseases or psychiatric disorders, received psychiatric help, and smoking.

\section{Caffeine consumption}

Caffeine intake per day was measured in milligrams. A table was included in the questionnaire (Table 1). The common caffeinated drinks had been enlisted in the table. All common caffeinated drinks were investigated, including drinks such as coffee, decaffeinated coffee, tea, cola, citrus, and energy drinks. The table included the size and the number of cup/cans per day for each drink. A reference image was attached to illustrate the size, and the amount of fluid in ounces. The participants were asked to fill out only the size and number of the drinks they regularly consume. The amount of caffeine in each drink size was calculated (Table 2), which were later multiplied by the number of cups/cans consumed daily. Then, the total numbers of caffeine milligrams per day were summed. Caffeine intake was examined as "low" and "high." Low intake was considered less than $250 \mathrm{mg}$ per day, while high intake was considered more than $250 \mathrm{mg}$ per day. The validity and reliability of measurements have been confirmed in similar studies $[10,11]$. 


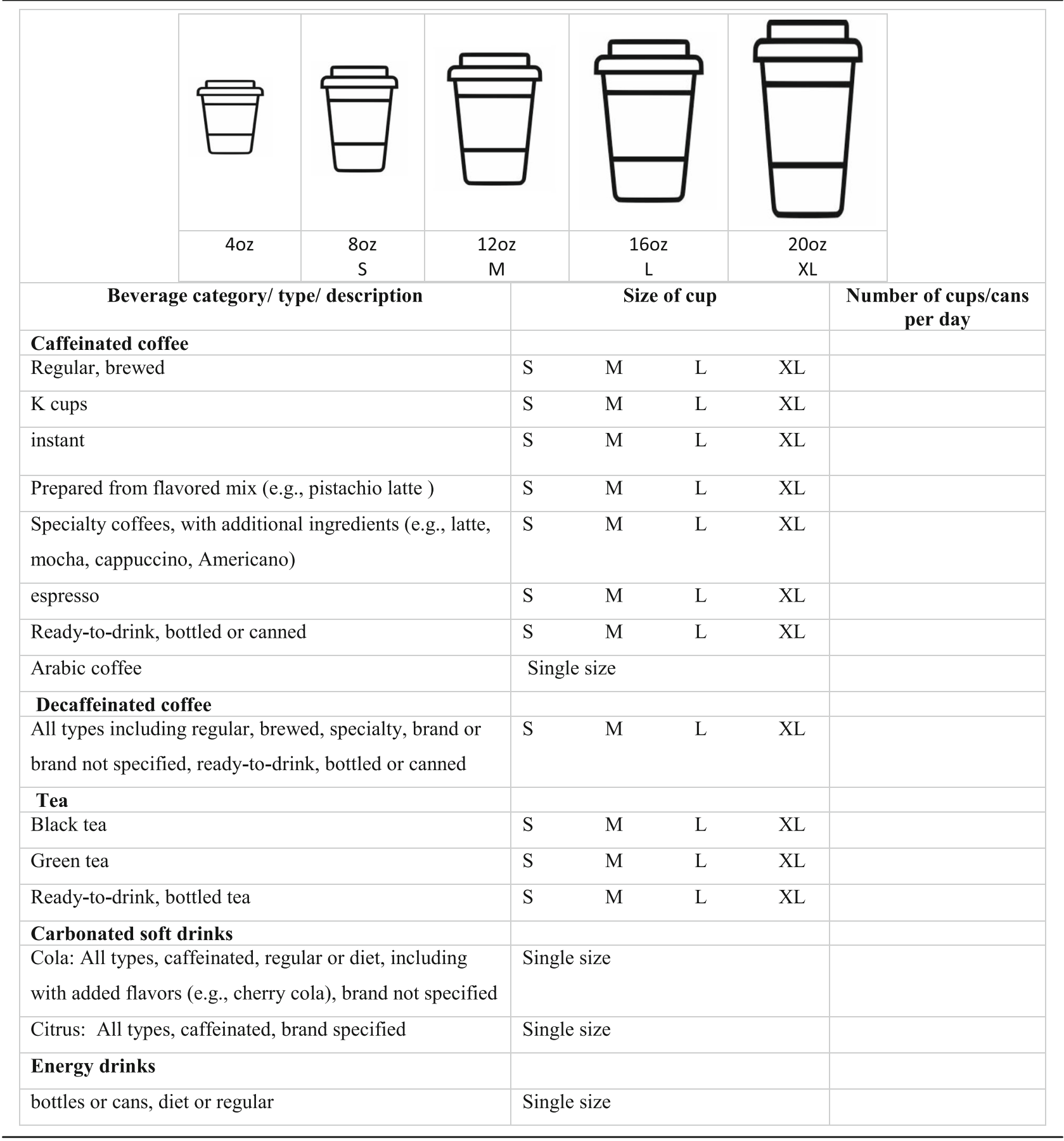

\section{Caffeine intoxication}

Intoxication was assessed using the criteria of DSM-5, which includes 12 symptoms. Participants were asked if they developed symptoms during or shortly after caffeine consumption. Any participant with five or more symptoms was diagnosed with caffeine intoxication according to the criteria.

\section{Perceived stress level}

Stress level was measured using the Arabic version of the PSS, which is a 10-question tool that is used to measure perception of stress over the past 30 days. The scale was developed in 1983 [12] and was modified in 1988 by Cohen [13]. It is a validated stress questionnaire with established acceptable psychometric properties [14, 15]. A Likert-type scale was used to capture responses to 
Table 2 Beverages caffeine content in mg/oz

\begin{tabular}{|c|c|c|c|c|}
\hline \multirow{3}{*}{ Type } & \multicolumn{3}{|c|}{$\mathrm{Mg} / \mathrm{oz}$} & \multirow[b]{3}{*}{$\mathrm{XL}$} \\
\hline & \multicolumn{3}{|l|}{ Size } & \\
\hline & $S$ & $M$ & L & \\
\hline Regular & 95.2 & 142.8 & 190.4 & 238 \\
\hline Arabic & 4.1 & & & \\
\hline K cups & 120 & 180 & 240 & 300 \\
\hline Instant & 75.2 & 122.8 & 150.4 & 188 \\
\hline Flavored & 48 & 72 & 96 & 120 \\
\hline Specialty & 94.8 & 142.2 & 189.6 & 237 \\
\hline Espresso & 219 & & & \\
\hline Canned coffee & 16.4 & 24.6 & 32.8 & 41 \\
\hline D-café & 2 & 3 & 4 & 5 \\
\hline Black tea & 47.2 & 70.8 & 94.4 & 118 \\
\hline Green tea & 24.8 & 37.2 & 49.6 & 62 \\
\hline Canned tea & 16 & 24 & 32 & 40 \\
\hline Cola & 24 & & & \\
\hline Citrus & 36.8 & & & \\
\hline Energy drinks & 80 & & & \\
\hline
\end{tabular}

the PSS ("never," "almost never," "sometimes," "fairly often," and "very often"). A score of $0-13$ is considered as low stress, 14-26 is considered moderate, and 27-40 is considered high perceived stress.

\section{Statistical analysis}

Data were analyzed using SPSS 23. We described the variables as means \pm the standard deviation $(\mathrm{SD})$ or percentages as appropriate. A $t$ test was used to determine the difference between quantitative variables, while the chi-squared test was used to determine the association between qualitative variables.

\section{Results}

Demographic characteristics, academic-related characteristics, and personal clinical history

The total number of participants in the study was 547, and the average age was $20.30 \pm 1.91$ years. The majority were Saudi (98.40\%) and single (96\%). More than half of the participants $(59.20 \%)$ reported that their income was enough, and $29.20 \%$ reported that their income was enough with saving.

Almost half of the participants were from health colleges $(50.10 \%)$, whereas the other half were from nonhealth colleges $(49.90 \%)$. More than half of the participants were junior students (61.80\%). The GPA 4.50-5.00 for $42.50 \%$ of the participants, and only $9.40 \%$ of them had a GPA less than 3.50. More than half of them were either satisfied or very satisfied with their academic achievement (46.60\% and $22.80 \%$, respectively).
A minority of the participants reported that they were diagnosed with chronic diseases and psychiatric disorders $(6.80 \%$ and $10.10 \%$, respectively). Half of those who had been diagnosed with a psychiatric disorder received psychiatric help (56.36\%). In addition, the majority of participants were non-smokers (93.90; Table 3).

\section{Caffeine consumption}

The mean total caffeine consumption per day was $424.69 \pm 385.31 \mathrm{mg}$. Specialty coffee was the most consumed caffeine source with a mean of $93.06 \pm 126.99 \mathrm{mg}$, followed by regular brewed coffee, capsule coffee, and black tea with means of $62.74 \pm 114.30 \mathrm{mg}, 55.39 \pm 114.62$ $\mathrm{mg}$, and $51.60 \pm 83.98 \mathrm{mg}$, respectively (Table 4). The mean of low caffeine consumption group $(<250 \mathrm{mg} /$ day) was $126.6 \pm 68.01 \mathrm{mg} /$ day, while it was $628.28 \pm 381.6$ $\mathrm{mg} /$ day for the high caffeine consumption group ( $>250$ $\mathrm{mg} /$ day).

A high level of caffeine consumption was significantly more evident among students of non-health colleges than health college students $(53.50 \%$ versus $46.50 \%$, respectively; $p<0.040$ ). In addition, a high level of caffeine consumption was significantly more evident among students undiagnosed with psychiatric disorders than diagnosed students $(87.60 \%$ versus $12.40 \%$, respectively; $p<0.027)$. Moreover, a high level of caffeine consumption was significantly more evident among students who experienced caffeine intoxication symptoms than asymptomatic students (75\% versus $57.1 \%$; $p<0.005)$. Finally, students who had a high level of caffeine consumption had significantly higher mean scores of perceived stress than students with a low level of caffeine consumption (21.40 \pm 6.38 and $20.27 \pm 6.31$, respectively; $p<0.045$; Table 5).

\section{Symptoms of caffeine intoxication}

The reported caffeine intoxication symptoms in descending order were diuresis, insomnia, tachycardia or arrhythmia, gastrointestinal disturbance, restlessness, nervousness, rambling flow of thought and speech, muscle twitching, periods of inexhaustibility, psychomotor agitation, excitement, and flushed face $(43.70 \%$, 43.50\%, 38.90\%, 25.80\%, 16.80\%, 15.90\%, 13.90\%, 11.70\%, $11 \%, 9.50 \%, 7.50 \%$, and $5.10 \%$, respectively). However, more than three quarters of them had no clinically significant distress or impairment of function (78\%). Only $13.26 \%$ of all participants fulfilled DSM-5 criteria for caffeine use disorder.

\section{Perceived stress}

More than two-thirds of the participants showed moderate stress levels (69.9\%), whereas $18.7 \%$ reported high stress levels (Table 6). There were significant associations between the level of perceived stress and academic satisfaction. A high level of stress was also more evident 
Table 3 Characteristics of study sample, $n=547$

\begin{tabular}{|c|c|}
\hline Item & Frequency (\%) \\
\hline Age (years) & $20.30 \pm 1.91$ \\
\hline \multicolumn{2}{|l|}{ Nationality } \\
\hline Saudi & $538(98.40 \%)$ \\
\hline Non-Saudi & $9(1.60 \%)$ \\
\hline \multicolumn{2}{|l|}{ Marital status $^{\mathrm{a}}$} \\
\hline Single & 524 (96.00\%) \\
\hline Married & $18(3.30 \%)$ \\
\hline Separated & $4(0.70 \%)$ \\
\hline \multicolumn{2}{|l|}{ Kids } \\
\hline Have kids & $9(1.70 \%)$ \\
\hline Does not have kids & $538(98.40 \%)$ \\
\hline \multicolumn{2}{|l|}{ Income ${ }^{a}$} \\
\hline Enough & $322(59.20 \%)$ \\
\hline Enough with saving & $159(29.20 \%)$ \\
\hline Not enough & 54 (9.90\%) \\
\hline In debt & $9(1.70 \%)$ \\
\hline \multicolumn{2}{|l|}{ College } \\
\hline Health & $274(50.10 \%)$ \\
\hline Non-health & $273(49.90 \%)$ \\
\hline \multicolumn{2}{|l|}{ Academic level } \\
\hline Junior & $338(61.80 \%)$ \\
\hline Senior & 209 (38.30\%) \\
\hline \multicolumn{2}{|l|}{$\mathrm{GPA}^{\mathrm{a}}$} \\
\hline $5-4.50$ & $228(42.50 \%)$ \\
\hline $4.49-4$ & $178(33.10 \%)$ \\
\hline $3.9-3.50$ & $80(14.90 \%)$ \\
\hline Less than 3.50 & $51(9.40 \%)$ \\
\hline \multicolumn{2}{|l|}{ Academic satisfaction $^{a}$} \\
\hline Very satisfied & $124(22.80 \%)$ \\
\hline Satisfied & $254(46.60 \%)$ \\
\hline Not satisfied & $121(22.20 \%)$ \\
\hline Very unsatisfied & $44(8.10 \%)$ \\
\hline \multicolumn{2}{|l|}{ Chronic diseases $^{\mathrm{a}}$} \\
\hline Diagnosed & $37(6.80 \%)$ \\
\hline Not diagnosed & 509 (93.20\%) \\
\hline \multicolumn{2}{|l|}{ Psychiatric disorders ${ }^{a}$} \\
\hline Diagnosed & $55(10.10 \%)$ \\
\hline Not diagnosed & 491 (89.90\%) \\
\hline \multicolumn{2}{|l|}{ Psychiatric help ${ }^{a}$} \\
\hline Received help & $30(54.50 \%)$ \\
\hline Did not receive & $23(41.80 \%)$ \\
\hline \multicolumn{2}{|l|}{ Smoking $^{a}$} \\
\hline Smoker & $33(6.10 \%)$ \\
\hline Non-smoker & $508(93.90 \%)$ \\
\hline
\end{tabular}

Values are presented as mean \pm standard deviation or number (\%)

${ }^{a}$ Missing data: 1: marital status, chronic disease, and psychiatric disorder. 2: academic satisfaction. 3: income and psychiatric help. 6: smoking. 10: GPA
Table 4 Caffeine consumption level (mg/day) by beverage category, $n=547$

\begin{tabular}{ll}
\hline Beverage category & Level \\
\hline Arabic coffee & $11.86 \pm 15.78$ \\
Regular brew coffee & $62.74 \pm 114.30$ \\
K cups & $55.39 \pm 114.62$ \\
Instant coffee & $46.47 \pm 95.86$ \\
Flavored coffee & $24.87 \pm 44.35$ \\
Specialty coffee & $93.06 \pm 126.99$ \\
Espresso coffee & $46.51 \pm 113.64$ \\
Canned coffee & $2.89 \pm 9.33$ \\
Decafe coffee & $0.21 \pm 0.92$ \\
Black tea & $51.60 \pm 83.98$ \\
Green tea & $7.07 \pm 19.94$ \\
Canned tea & $3.08 \pm 9.87$ \\
Cola & $10.70 \pm 16.91$ \\
Citrus & $5.25 \pm 15.51$ \\
Energy drinks & $11.40 \pm 36.05$ \\
Total caffeine consumption & $424.69 \pm 385.31$ \\
\hline Values are presented as mean \pm standard deviation &
\end{tabular}

among students who were academically very unsatisfied or not satisfied than those who were satisfied or very satisfied ( $25.87 \pm 6.57$ and $22.43 \pm 6.20$ versus $20.23 \pm 5.95$ and $19.33 \pm 6.17$, respectively; $p<0.001)$.

In addition, the level of perceived stress was significantly associated with students' income; a higher level of stress was more evident among students who expressed that they were in debt or their income is not enough those who had enough income or enough income with savings $(24.11 \pm 6.95$ and $23.24 \pm 7.90$ versus $20.99 \pm 5.75$ and $20.16 \pm 6.69$, respectively; $p<0.008$ ). Another significant association was found between the level of perceived stress and some personal clinical histories. A high level of stress was more evident among students who were diagnosed with psychiatric disorders than undiagnosed students $(25.20 \pm 6.31$ versus $20.52 \pm 6.20$, respectively; $p<0.001)$. The level of stress was also significantly higher among students diagnosed with chronic disease than undiagnosed students $(23.69 \pm 6.17$ versus $20.80 \pm$ 6.33, respectively; $p<0.008$ ). Furthermore, a high level of stress was more evident among smokers than nonsmokers (24.36 \pm 7.44 versus $20.79 \pm 0.02$, respectively; $p<$ 0.002). Finally, a high level of stress was more evident among students who experienced caffeine intoxication symptoms than asymptomatic students $(24.12 \pm 5.92$ than $20.51 \pm 6.28$, respectively; $p<0.001$; Table 7 ).

\section{Discussion}

This study represents the first Saudi university-based survey of caffeine consumption including all types of 
Table 5 Characteristics of the subjects according to caffeine consumption level

\begin{tabular}{ll}
\hline Characteristic & Caffeine cons \\
\cline { 2 - 2 } $\begin{array}{l}\text { Age (year) } \\
\text { College }\end{array}$ & $20.38 \pm 1.962$ \\
Health & $119(55.60 \%)$ \\
Non-health & $95(44.40 \%)$ \\
Nationality & \\
$\quad$ Saudi & $208(97.20 \%)$ \\
$\quad$ Non-Saudi & $6(2.80 \%)$ \\
Marital status & \\
Single & \\
Married & $205(96.20 \%)$ \\
Separated & $6(2.80 \%)$ \\
Kids & $2(0.90 \%)$ \\
Have kids & \\
Does not have kids & $1(0.50 \%)$ \\
Income & $213(99.50 \%)$ \\
Enough & \\
Enough with saving & $125(58.70 \%)$ \\
Not enough & $70(32.90 \%)$ \\
In debt & $16(7.20 \%)$ \\
Academic leve & $2(0.90 \%)$ \\
\hline
\end{tabular}

\section{Academic level}

$\begin{array}{ll}\text { Junior } & 130(60.70 \%) \\ \text { Senior } & 84(39.30 \%) \\ \text { GPA }^{\text {a }} & \\ 5-4.50 & 95(45.70 \%) \\ 4.49-4 & 64(30.80 \%) \\ 3.9-3.50 & 30(14.40 \%) \\ \text { Less than } 3.50 & 19(9.10 \%)\end{array}$

Academic satisfaction $^{a}$

Very satisfied

Satisfied

Not satisfied

Very unsatisfied

Chronic diseases $^{a}$

$$
\begin{aligned}
& \text { Diagnosed } \\
& \text { Not diagnosed }
\end{aligned}
$$

Psychiatric disorders ${ }^{\mathrm{a}}$

$$
\begin{aligned}
& \text { Diagnosed } \\
& \text { Not diagnosed }
\end{aligned}
$$

Psychiatric help ${ }^{a}$

Received help

Did not receive

Smoking ${ }^{a}$

Smoker
$48(22.50 \%)$

$109(51.20 \%)$

45 (21.10\%)

$10(4.70 \%)$

17 (7.90\%)

$197(92.10 \%)$

$14(6.50 \%)$

$200(93.50 \%)$

$$
\begin{aligned}
& 8(61.50 \%) \\
& 5(38.50 \%)
\end{aligned}
$$

$11(36.70 \%)$
$20.25 \pm 1.90$
$146(46.50 \%)$
$168(53.50 \%)$ value 0.466 0.040

$311(99.00 \%)$

$3(1.00 \%)$

0.766

300 (95.50\%)

$12(3.80 \%)$

$2(0.60 \%)$

0.070

8 (2.50\%)

$306(97.50 \%)$

$188(60.30 \%)$

$83(26.60 \%)$

$36(11.50 \%)$

$5(1.60 \%)$

0.698

196 (62.40\%)

118 (37.60\%)

0.553

$123(39.70 \%)$

111 (35.80\%)

48 (15.50\%)

$28(9.00 \%)$

71 (22.70\%)

136 (43.50\%)

73 (23.30\%)

32 (10.20\%)

0.402

19 (6.10\%)

294 (93.90\%)

39 (12.40\%)

275 (87.60\%)

21 (55.30\%)

17 (44.70\%)

19 (63.30\%) 
Table 5 Characteristics of the subjects according to caffeine consumption level (Continued)

\begin{tabular}{|c|c|c|c|}
\hline \multirow[t]{2}{*}{ Characteristic } & \multicolumn{2}{|l|}{ Caffeine consumption (mg/day) } & \multirow{2}{*}{$\begin{array}{l}P \\
\text { value }\end{array}$} \\
\hline & Low level $(<250 \mathrm{mg}) n=214$ & High level $(>250 \mathrm{mg}) n=314$ & \\
\hline Non-smoker & $198(40.20 \%)$ & $295(59.80 \%)$ & \\
\hline Caffeine intoxication $^{a}$ & & & 0.005 \\
\hline Intoxication symptoms & $17(25.00 \%)$ & $51(75.00 \%)$ & \\
\hline No intoxication symptoms & $196(42.90 \%)$ & $261(57.10 \%)$ & \\
\hline Perceived stress scale & $20.27 \pm 6.31$ & $21.40 \pm 6.38$ & 0.045 \\
\hline
\end{tabular}

Values are presented as mean \pm standard deviation or number (\%)

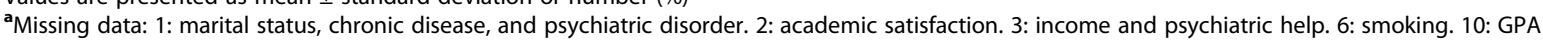

caffeinated beverages among students from both health and non-health colleges to explore the correlation with perceived stress and caffeine intoxication. The results showed that the mean total caffeine consumption was $424.69 \pm 385.31 \mathrm{mg} /$ day. This could be alarming as the recommended use for healthy adult is $400 \mathrm{mg} /$ day [16]. This result is comparable to that of an Egyptian study, which found that caffeine consumption was 405.47 \pm $396.43 \mathrm{mg} /$ day among university students [17]. These two results are slightly higher than a Lebanese result that showed a mean total caffeine consumption of $193.32 \pm 361.81 \mathrm{mg} /$ day for medical students [18]. This can be explained by the result of the current study as it showed higher caffeine consumption among non-health college student. The lower caffeine consumption level reported by students of health colleges could be due to their awareness about the side effects of caffeine. On the other hand, the total mean caffeine consumption in the current study is much higher (by at least twice) than in other studies that were conducted among another various populations, like army soldiers $(285 \mathrm{mg} /$ day), psychiatric patients $(281 \pm 325 \mathrm{mg} /$ day), office workers (205.7 \pm $34.9 \mathrm{mg} /$ day), the general populations $(164.5 \pm 0.9 \mathrm{mg} /$ day and $193 \mathrm{mg} /$ day), adolescents $(25.92 \pm 41.25 \mathrm{mg} /$ day and $91.5 \pm 4.7 \mathrm{mg} /$ day), and children $(76.1 \pm 6.3 \mathrm{mg} /$ day) $[10,11,19-22]$. This could be due to the higher level of perceived stress that was found among university students in this study as caffeine may relieve stress [23]. In addition, other numerous factors for caffeine intake among undergraduate university students were reported in the USA including improving alertness, concentration, mood, energy, and enjoying the taste [24].

Furthermore, the level of caffeine consumption was significantly lower among students diagnosed with psychiatric disorders, which could be attributed to their awareness or previous experience of the effects of excessive caffeine consumption, which increases the risk of anxiety, panic attacks, and psychotic symptoms $[25,26]$.

Table 6 Responses to the perceived stress scale from students, $n=546$

\begin{tabular}{|c|c|c|c|c|c|}
\hline Perceived stress scale & Never & $\begin{array}{l}\text { Almost } \\
\text { never }\end{array}$ & Sometimes & $\begin{array}{l}\text { Fairly } \\
\text { often }\end{array}$ & $\begin{array}{l}\text { Very } \\
\text { often }\end{array}$ \\
\hline $\begin{array}{l}\text { 1. In the last month, how often have you been upset because } \\
\text { of something that happened unexpectedly? }\end{array}$ & $137(25.10 \%)$ & $97(17.80 \%)$ & $175(32.10 \%)$ & $84(15.40 \%)$ & $53(9.70 \%)$ \\
\hline $\begin{array}{l}\text { 2. In the last month, how often have you felt that you were } \\
\text { unable to control the important things in your life? }\end{array}$ & $79(14.50 \%)$ & $103(18.90 \%)$ & $179(32.80 \%)$ & $114(20.90 \%)$ & $70(12.80 \%)$ \\
\hline 3. In the last month, how often have you felt nervous and "stressed?" & $48(8.80 \%)$ & $49(9.00 \%)$ & $153(28.00 \%)$ & $160(29.30 \%)$ & $136(24.90 \%)$ \\
\hline $\begin{array}{l}\text { 4. In the last month, how often have you felt confident about } \\
\text { your ability to handle your personal problems? }\end{array}$ & $53(9.70 \%)$ & $77(14.10 \%)$ & 188 (34.40\%) & 167 (30.60\%) & $61(11.20 \%)$ \\
\hline $\begin{array}{l}\text { 5. In the last month, how often have you felt that things were } \\
\text { going your way? }\end{array}$ & 89 (16.30\%) & 140 (25.60\%) & 193 (35.30\%) & 99 (18.10\%) & $25(4.60 \%)$ \\
\hline $\begin{array}{l}\text { 6. In the last month, how often have you found that you could } \\
\text { not cope with all the things that you had to do? }\end{array}$ & 69 (12.60\%) & 96 (17.60\%) & 218 (39.90\%) & 109 (20.00\%) & $54(9.90 \%)$ \\
\hline $\begin{array}{l}\text { 7. In the last month, how often have you been able to control } \\
\text { irritations in your life? }\end{array}$ & 63 (11.50\%) & 127 (23.30\%) & 209 (38.30\%) & 119 (21.80\%) & $28(5.10 \%)$ \\
\hline $\begin{array}{l}\text { 8. In the last month, how often have you felt that you were on } \\
\text { top of things? }\end{array}$ & $74(13.60 \%)$ & 130 (23.80\%) & 224 (41.00\%) & 102 (18.70\%) & $16(2.90 \%)$ \\
\hline $\begin{array}{l}\text { 9. In the last month, how often have you been angered because } \\
\text { of things that were outside of your control? }\end{array}$ & $48(8.80 \%)$ & $84(15.40 \%)$ & 165 (30.20\%) & 155 (28.40\%) & 94 (17.20\%) \\
\hline $\begin{array}{l}\text { 10. In the last month, how often have you felt difficulties were } \\
\text { piling up so high that you could not overcome them? }\end{array}$ & 75 (13.70\%) & $120(22.00 \%)$ & 157 (28.80\%) & 103 (18.90\%) & 91 (16.70\%) \\
\hline
\end{tabular}


Table $\mathbf{7}$ Characteristics of the subjects according to perceived stress level, $n=547$

\begin{tabular}{|c|c|c|}
\hline Item & Mean \pm SD & $P$ value \\
\hline Age (year) & $20.29 \pm 1.91$ & 0.105 \\
\hline College & & 0.135 \\
\hline Health & $21.39 \pm 6.72$ & \\
\hline Non-health & $20.57 \pm 5.94$ & \\
\hline Nationality & & 0.100 \\
\hline Saudi & $20.93 \pm 6.36$ & \\
\hline Non-Saudi & $24.44 \pm 4.71$ & \\
\hline Marital status ${ }^{a}$ & & 0.785 \\
\hline Single & $21.00 \pm 6.36$ & \\
\hline Married & $20.55 \pm 6.17$ & \\
\hline Separated & $23.00 \pm 6.21$ & \\
\hline Kids & & 0.755 \\
\hline Have kids & $20.33 \pm 5.31$ & \\
\hline Does not have kids & $21.00 \pm 6.37$ & \\
\hline Income ${ }^{a}$ & & 0.008 \\
\hline Enough & $20.99 \pm 5.75$ & \\
\hline Enough with saving & $20.16 \pm 6.69$ & \\
\hline Not enough & $23.24 \pm 7.90$ & \\
\hline In debt & $24.11 \pm 6.95$ & \\
\hline Academic level & & 0.460 \\
\hline Junior & $20.83 \pm 6.26$ & \\
\hline Senior & $21.24 \pm 6.51$ & \\
\hline $\mathrm{GPA}^{\mathrm{a}}$ & & 0.329 \\
\hline $5-4.50$ & $20.48 \pm 6.25$ & \\
\hline $4.49-4$ & 21.15.6.41 & \\
\hline $3.99-3.50$ & $21.86 \pm 6.27$ & \\
\hline Less than 3.49 & $21.50 \pm 6.05$ & \\
\hline Academic satisfaction $^{a}$ & & $<0.001$ \\
\hline Very satisfied & $19.33 \pm 6.17$ & \\
\hline Satisfied & $20.23 \pm 5.95$ & \\
\hline Not satisfied & $22.43 \pm 6.20$ & \\
\hline Very unsatisfied & $25.86 \pm 6.57$ & \\
\hline Chronic diseases $^{\mathrm{a}}$ & & 0.008 \\
\hline Diagnosed & $23.69 \pm 6.17$ & \\
\hline Not diagnosed & $20.80 \pm 6.33$ & \\
\hline Psychiatric disorders $^{\mathrm{a}}$ & & $<0.001$ \\
\hline Diagnosed & $25.20 \pm 6.31$ & \\
\hline Not diagnosed & $20.52 \pm 6.20$ & \\
\hline Psychiatric help ${ }^{a}$ & & 0.618 \\
\hline Received help & $24.79 \pm 7.39$ & \\
\hline Did not receive & $25.69 \pm 4.98$ & \\
\hline Smoking $^{a}$ & & 0.002 \\
\hline Smoker & $24.36 \pm 7.44$ & \\
\hline
\end{tabular}

Table 7 Characteristics of the subjects according to perceived stress level, $n=547$ (Continued)

\begin{tabular}{|c|c|c|}
\hline Item & Mean \pm SD & $P$ value \\
\hline Non-smoker & $20.79 \pm 0.02$ & \\
\hline Caffeine intake $^{a}$ & & 0.045 \\
\hline Low $(<250 \mathrm{~g})$ & $20.27 \pm 6.31$ & \\
\hline High (>250 g) & $21.40 \pm 6.38$ & \\
\hline Caffeine intoxication ${ }^{a}$ & & $<0.001$ \\
\hline Intoxication symptoms & $24.12 \pm 5.92$ & \\
\hline No intoxication symptoms & $20.51 \pm 6.28$ & \\
\hline
\end{tabular}

And those who are suffering from anxiety conditions may have more caffeine sensitivity, which contribute in caffeine avoidance due to the undesirable effects [2729]. It could also be attributed to their awareness or previous experience with the potential interaction of caffeine with psychotropic drugs that are used for their psychiatric conditions, which is due to the metabolism of caffeine by CYP1A2 enzyme. Caffeine can inhibit this enzyme and cause side effects that may affect their treatment plan [30]. In addition, a high level of caffeine consumption was significantly more evident among students who experienced caffeine intoxication because the more caffeine they consume, the more symptoms they experience. A related study done in the USA showed that excessive caffeine consumption can lead to caffeine intoxication [4]. And it was found that only $13 \%$ of participants experienced caffeine intoxication according to the DSM-5 criteria. This is similar to the prevalence of intoxication that was found among psychiatric patients in Italy (10.3\%), which was significantly higher compared to healthy participants (2.9\%). However, comparing our results with the Italian results was limited by the samples differences as the Italian study had wider age range and more severe psychiatric cases compared to our study [22].

Perceived stress was prevalent in this study. This is not surprising as similar results were found in previous studies that were conducted among university students in Saudi Arabia, Iran, and Malaysia [5, 31-33]. In addition, a significant positive relationship was found between the level of caffeine consumption and the level of perceived stress. This is supported by a previous study that found a significant positive relationship between the consumption of energy drinks and stress $[34,35]$. This might be due to the beneficial effects of caffeine in maintaining cognitive function under conditions of stress and improving work performance [23].

Moreover, smoker students reported significantly higher stress levels. There are several theories on the 
role of stress and smoking behaviors. Smokers use cigarettes to relieve stress. However, several studies have shown that while smoking may temporarily relieve perceived stress, it actually may generate or aggravate negative emotional states and propagate negative coping strategies, leading to higher stress levels overall [36].

Perceived stress was found to be significantly higher among students who were diagnosed with psychiatric disorder or chronic disease. This is not surprising as it is evident that stress is a risk factor for various psychiatric and medical conditions [37-40]. Research shows that almost every system in the body can be influenced by chronic stress. When chronic stress goes unreleased, it suppresses the body's immune system and ultimately manifests as illness. If stress continues and the body is unable to cope, there is likely to be a breakdown of bodily resources [41].

\section{Limitations}

This is the first Saudi university-based survey of caffeine consumption among students from both health and non-health colleges that included all types of caffeinated beverages. The results provided valuable information about caffeine consumption, caffeine intoxication, and stress. However, the convenience sampling and female participants limit the generalizability of the study. Although all common caffeinated drinks were investigated in this study, other possible sources of caffeine such as caffeine pills and chocolate were not included. In addition, even if intoxication symptoms listed in the survey were developed during or shortly after caffeine intake, it was difficult to differentiate between caffeine intoxication and symptoms of other medical or psychiatric conditions. Furthermore, a cross-sectional study cannot identify causality relationships.

\section{Conclusion}

Caffeine is highly consumed by female undergraduate students, mostly specially coffee, and the level is significantly higher among students of non-health colleges. In addition, caffeine consumption levels are positively and significantly correlated with perceived stress levels, which were prevalent among the students. However, only $13.26 \%$ of all participants fulfilled DSM- 5 criteria for caffeine use disorder which was associated with high level of stress. This emphasizes the importance of educational campaigns about caffeine consumption and intoxication. Furthermore, this study could be useful for future university education and stress management planning. It could also be used as a primary resource for future investigations. However, longitudinal studies need to be designed for evidence-based intervention. Further studies also need to involve both sexes and postgraduate students.

\section{Abbreviations}

PSS: Perceived stress scale; DSM-5: The Diagnostic and Statistical Manual of Mental Disorders, fifth edition

\section{Acknowledgements}

The authors would like to thank Prof. Amel Fayed and Prof. Halah Elmershardi.

\section{Authors' contributions}

RMA and NA were responsible of designing the study. MA and RM were in charge of collecting and entering the data. And they helped in the analysis. RMA and RIA were responsible of interpreting and analyzing of the data. DA was responsible of the general process, editing, and publication of paper. All authors took a part in writing, revising and approving the final manuscript. The authors read and approved the final manuscript.

\section{Funding}

This research was funded by the Deanship of Scientific Research at Princess Nourah Bint Abdulrahman University through the Fast-track Research Funding Program. The funding body has no role in study design, data collection, data analysis, data interpretation, or manuscript writing.

Availability of data and materials

All data and material of this study are available upon request from the corresponding author.

\section{Declarations}

\section{Ethics approval and consent to participate}

Ethical approval was obtained from the Institutional Review Board at Princess Nourah bint Abdulrahman University, Riyadh, KSA (IRB-PNU:19-0234), on 20 November 2019. Informed verbal consent was acquired from all participants before enrollment in the study. The ethics committee approved the verbal consent. Using verbal consent was recommended by the IRB in surveys if the data was taken from human subjects who cannot be identified, and their responses could not put them at risk of criminal or civil liability and could not damage their reputation or employability.

\section{Consent for publication}

Not applicable.

\section{Competing interests}

No conflict of interest.

Received: 28 December 2020 Accepted: 27 April 2021

Published online: 15 June 2021

\section{References}

1. Uddin MS, Abu Sufian M, Hossain MF, Kabir MT, Islam MT, Rahman MM et al (2017) Neuropsychological effects of caffeine: is caffeine addictive? J Psychol Psychother 07(02):1-12

2. Richards G, Smith A (2015) Caffeine consumption and self-assessed stress, anxiety, and depression in secondary school children. J Psychopharmacol. 29(12):1236-1247. https://doi.org/10.1177/0269881115612404

3. American Psychiatric Association (2012) DSM-IV and DSM-5 criteria for the personality disorders. Am Psychiatr Assoc. p. 503-4 in Section II (SubstanceRelated and Addictive Disorders)

4. Simpson E, Stephenson T, Brewer D, Schwartz A, Bastin S (2016) Perceived stress, caffeine consumption, and GPA of undergraduate students at a large public university. J Nutr Educ Behav. 48(7):S102. https://doi.org/10.1016/j. jneb.2016.04.269

5. Aftab MT, Naqvi AA, Al-karasneh AF, Ghori SA (2018) Impact of religiosity on subjective life satisfaction and perceived academic stress in undergraduate pharmacy students. J Pharm Bioallied Sci 10(4):192-198

6. Karagoz I (2019) Cmbebih 2019. IFMBE Proc - C. 73:159-163

7. Jahrami H, Al-Mutarid M, Penson PE, Al-Islam Faris M, Saif Z, Hammad L (2020) Intake of caffeine and its association with physical and mental health status among university students in Bahrain. Foods (Basel, Switzerland) 9(4):473

8. Alfajahan OAA (2018) Sleep habits and caffeine consumption in undergraduate female students in Saudi Arabia 
9. Chaaya M, Osman H, Naassan G, Mahfoud Z (2010) Validation of the Arabic version of the Cohen perceived stress scale (PSS-10) among pregnant and postpartum women. BMC Psychiatry 10(111):1-7

10. Jin MJ, Yoon CH, Ko HJ, Kim HM, Kim AS, Moon HN, Jung SP (2016) The relationship of caffeine intake with depression, anxiety, stress, and sleep in Korean adolescents. Korean J Fam Med. 37(2):111-116. https://doi.org/10.4 082/kjfm.2016.37.2.111

11. Mitchell DC, Knight CA, Hockenberry J, Teplansky R, Hartman TJ (2014) Beverage caffeine intakes in the U.S. Food Chem Toxicol 63:136-142

12. Cohen S, Kamarck T, Mermelstein R (1983) A global measure of perceived stress. J Health Soc Behav. 24(4):385-396. https://doi.org/10.2307/2136404

13. Cohen S (1988) Perceived stress in a probability sample of the United States. In: The social psychology of health. Sage Publications, Inc, Thousand Oaks, pp 31-67 (The Claremont Symposium on Applied Social Psychology.)

14. Lee EH (2012) Review of the psychometric evidence of the perceived stress scale. Asian Nurs Res (Korean Soc Nurs Sci). 6(4):121-127. https://doi.org/1 0.1016/j.anr.2012.08.004

15. Taylor JM (2015) Psychometric analysis of the ten-item perceived stress scale. Psychol Assess. 27(1):90-101. https://doi.org/10.1037/a0038100

16. Knight CA, Knight I, Mitchell DC, Zepp JE (2004) Beverage caffeine intake in US consumers and subpopulations of interest: estimates from the Share of Intake Panel survey. Food Chem Toxicol. 42(12):1923-1930. https://doi.org/1 0.1016/j.fct.2004.05.002 Available from: https://www.sciencedirect.com/ science/article/pii/S0278691504001589

17. El-Nimr N, Bassiouny S, Tayel D (2019) Pattern of caffeine consumption among university students. J High Inst Public Heal. 0(0):153-160. https://doi. org/10.21608/jhiph.2019.56579

18. Samaha A, Al Tassi A, Yahfoufi N, Gebbawi M, Rached M, Fawaz MA (2020) Data on the relationship between caffeine addiction and stress among Lebanese medical students in Lebanon. Data Br. 28:104845. https://doi.org/1 0.1016/j.dib.2019.104845

19. Misaizu A, Kokubo T, Tazumi K, Kanayama M, Miura Y (2014) The combined effect of caffeine and ornithine on the mood of healthy office workers. Prev Nutr Food Sci. 19(4):367-372. https://doi.org/10.3746/pnf.2014.19.4.367

20. Frary CD, Johnson RK, Wang MQ (2005) Food sources and intakes of caffeine in the diets of persons in the United States. J Am Diet Assoc. 105(1):110-113. https://doi.org/10.1016/j.jada.2004.10.027 Available from: https://www.sciencedirect.com/science/article/pii/S000282230401702X

21. Lieberman HR, Stavinoha T, McGraw S, White A, Hadden L, Marriott BP (2012) Caffeine use among active duty US army soldiers. J Acad Nutr Diet 112(6):902-912.e4 Available from: https://www.sciencedirect.com/science/a rticle/pii/S2212267212001530

22. Ciapparelli A, Paggini R, Carmassi C, Taponecco C, Consoli G, Ciampa G et al (2020) Patterns of caffeine consumption in psychiatric patients. An Italian study. Eur Psychiatry 25(4):230-235 Available from: https://www.cambridge. org/core/article/patterns-of-caffeine-consumption-in-psychiatric-patients-anitalian-study/FE266821259A551A179369AFDED4584C

23. Lieberman HR, Tharion WJ, Shukitt-Hale B, Speckman KL, Tulley R (2002) Effects of caffeine, sleep loss, and stress on cognitive performance and mood during U.S. Navy SEAL training. Psychopharmacology (Berl). 164(3): 250-261. https://doi.org/10.1007/s00213-002-1217-9

24. Mahoney CR, Giles GE, Marriott BP, Judelson DA, Glickman EL, Geiselman PJ, Lieberman HR (2019) Intake of caffeine from all sources and reasons for use by college students. Clin Nutr. 38(2):668-675. https://doi.org/10.1016/j.clnu.2 018.04.004 Available from: https://www.sciencedirect.com/science/article/pii/ S0261561418301341

25. Addicott MA (2014) Caffeine use disorder: a review of the evidence and future implications. Curr Addict Reports. 1(3):186-192. https://doi.org/10.1 007/s40429-014-0024-9

26. Lara DR (2010) Caffeine, mental health, and psychiatric disorders. J Alzheimer's Dis 20(SUPPL.1):S239-S248

27. Lee MA, Cameron OG, Greden JF (1985) Anxiety and caffeine consumption in people with anxiety disorders. Psychiatry Res. 15(3):211-217. https://doi. org/10.1016/0165-1781(85)90078-2 Available from: https://www. sciencedirect.com/science/article/pii/0165178185900782

28. Lande RG, Labbate LA (1998) Caffeine use and plasma concentrations in psychiatric outpatients. Depress Anxiety 7(3):130-133. Available from:. https://doi.org/10.1002/(SICI)1520-6394(1998)7:3\%3C130::AID-DA6\%3E3.0.CO

29. Boulenger JP, Uhde TW (1982) Caffeine consumption and anxiety: preliminary results of a survey comparing patients with anxiety disorders and normal controls. Psychopharmacol Bull. 18(4):53-57 Available from: http://europepmc.org/abstract/MED/7156298

30. Broderick PJ, Benjamin AB, Dennis LW (2005) Caffeine and psychiatric medication interactions: a review. J Okla State Med Assoc. 98(8):380-384 Available from: http://europepmc.org/abstract/MED/16206866

31. Al-sowygh ZH (2013) Academic distress, perceived stress and coping strategies among dental students in Saudi Arabia. Saudi Dent J. 25(3):97105. Available from:. https://doi.org/10.1016/j.sdentj.2013.05.002

32. Moayedi F, Bastami MM, Ashouri FP, Hamadiyan H, Rasekhi S (2016) Comparison of sources and severity of perceived stress between paramedical and medical students. Int J Med Res Heal Sci. 6:183-190

33. Al-Dubai SA, Barua A, Ganasegeran K, Jadoo SA, Rampal KG (2014) Concurrent validity of the Malay version of Perceived Stress Scale (PSS-10) ASEAN J Psychiatry. 15:8-13

34. Pettit ML, Debarr KA (2011) Perceived stress, energy drink consumption, and academic performance among college students. J Am Coll Heal. 59(5):335341. https://doi.org/10.1080/07448481.2010.510163

35. Errisuriz VL, Pasch KE, Perry CL (2016) Perceived stress and dietary choices: the moderating role of stress management. Eat Behav. 22:211-216. https:// doi.org/10.1016/j.eatbeh.2016.06.008

36. Lawless MH, Harrison KA, Grandits GA, Eberly LE, Allen SS (2015) Perceived stress and smoking-related behaviors and symptomatology in male and female smokers. Addict Behav. 51:80-83. https://doi.org/10.1016/j.addbeh.2 015.07.011

37. Sinha R, Jastreboff AM (2013) Stress as a common risk factor for obesity and addiction. Biol Psychiatry. 73(9):827-835. https://doi.org/10.1016/..biopsych.2 013.01.032 Available from: https://www.sciencedirect.com/science/article/pii/ S0006322313001340

38. Vanltallie TB (2002) Stress: a risk factor for serious illness. Metab - Clin Exp 51(6):40-45. Available from. https://doi.org/10.1053/meta.2002.33191

39. Kivimäki M, Kawachi I (2015) Work stress as a risk factor for cardiovascular disease. Curr Cardiol Rep 17(9):74. Available from:. https://doi.org/10.1007/ s11886-015-0630-8

40. Wang J (2005) Work stress as a risk factor for major depressive episode (s) Psychol Med. 35(6):865-871. https://doi.org/10.1017/S0033291704003241

41. Salleh MR (2008) Life event, stress and illness. Malaysian J Med Sci. 15(4):9-18

\section{Publisher's Note}

Springer Nature remains neutral with regard to jurisdictional claims in published maps and institutional affiliations.

\section{Submit your manuscript to a SpringerOpen ${ }^{\circ}$ journal and benefit from:}

- Convenient online submission

- Rigorous peer review

- Open access: articles freely available online

- High visibility within the field

- Retaining the copyright to your article

Submit your next manuscript at $>$ springeropen.com 